\title{
Deglacial sea level history of the East Siberian Sea and Chukchi Sea margins
}

\author{
Thomas M. Cronin ${ }^{1}$, Matt O’Regan ${ }^{2}$, Christof Pearce ${ }^{2}$, Laura Gemery ${ }^{1}$, Michael Toomey ${ }^{1}$, Igor Semiletov ${ }^{3,4}$, and \\ Martin Jakobsson ${ }^{2}$ \\ ${ }^{1}$ US Geological Survey MS 926A, Reston, Virginia 20192, USA \\ ${ }^{2}$ Department of Geological Sciences and Bolin Centre for Climate Research, Stockholm University, \\ 10691 Stockholm, Sweden \\ ${ }^{3}$ Pacific Oceanological Institute, Russian Academy Sciences, Vladivostok, Russia \\ ${ }^{4}$ Tomsk Polytechnic University, Tomsk, Russia \\ Correspondence to: Thomas M. Cronin (tcronin@usgs.gov)
}

Received: 13 February 2017 - Discussion started: 29 March 2017

Revised: 14 July 2017 - Accepted: 31 July 2017 - Published: 5 September 2017

\begin{abstract}
Deglacial (12.8-10.7 ka) sea level history on the East Siberian continental shelf and upper continental slope was reconstructed using new geophysical records and sediment cores taken during Leg 2 of the 2014 SWERUS-C3 expedition. The focus of this study is two cores from Herald Canyon, piston core SWERUS-L2-4-PC1 (4-PC1) and multicore SWERUS-L2-4-MC1 (4-MC1), and a gravity core from an East Siberian Sea transect, SWERUS-L2-20-GC1 (20GC1). Cores 4-PC1 and 20-GC were taken at 120 and $115 \mathrm{~m}$ of modern water depth, respectively, only a few meters above the global last glacial maximum (LGM; $\sim 24$ kiloannum or ka) minimum sea level of $\sim 125-130$ meters below sea level (m b.s.l.). Using calibrated radiocarbon ages mainly on molluscs for chronology and the ecology of benthic foraminifera and ostracode species to estimate paleodepths, the data reveal a dominance of river-proximal species during the early part of the Younger Dryas event (YD, Greenland Stadial GS-1) followed by a rise in river-intermediate species in the late Younger Dryas or the early Holocene (Preboreal) period. A rapid relative sea level rise beginning at roughly 11.4 to $10.8 \mathrm{ka}(\sim 400 \mathrm{~cm}$ of core depth) is indicated by a sharp faunal change and unconformity or condensed zone of sedimentation. Regional sea level at this time was about $108 \mathrm{~m}$ b.s.l. at the 4-PC1 site and $102 \mathrm{~m}$ b.s.l. at 20-GC1. Regional sea level near the end of the YD was up to $42-47 \mathrm{~m}$ lower than predicted by geophysical models corrected for glacio-isostatic adjustment. This discrepancy could be explained by delayed isostatic adjustment caused by a greater volume and/or geo-
\end{abstract}

graphical extent of glacial-age land ice and/or ice shelves in the western Arctic Ocean and adjacent Siberian land areas.

\section{Introduction}

Rates and patterns of global sea level rise (SLR) following the last glacial maximum (LGM) are known from radiometric ages on coral reefs from Barbados, Tahiti, New Guinea, and the Indian Ocean, as well as sediment records from the Sunda Shelf and elsewhere. These records provide estimated global and regional rates of SLR when combined with LGM and deglacial ice sheet history and geophysical models of regionally varying glacio-isostatic adjustment (GIA) to changing land ice mass. For example, Lambeck et al. (2014) estimate mean global rates during the main deglaciation phase of 16.5 to 8.2 kiloannum (ka) at $12 \mathrm{~mm} \mathrm{yr}^{-1}$ with more rapid SLR rates $\left(\sim 40 \mathrm{~mm} \mathrm{yr}^{-1}\right)$ during meltwater pulse 1A $\sim 14.5-14.0 \mathrm{ka}$ and slower rates during the Younger Dryas (YD) from 12.5 to $11.5 \mathrm{ka}$. Importantly for our discussion, Lambeck et al. (2014) do not find evidence for rapid SLR during meltwater pulse 1B $\sim 11.3 \mathrm{ka}$. The ICE-6G sea level model of Peltier et al. (2015; see also Argus et al., 2014) also provides spatially varying rates of vertical land motion focused on regions of major ice sheets of North America, Fennoscandia, Antarctica, and regions peripheral to ice sheets. ICE-6G provides a general model against which new regional sea level curves may be compared. 
Table 1. SWERUS-C3 Leg 2 core data.

\begin{tabular}{lllrrr}
\hline Core ID & Lat $(\mathrm{N}) \_$aft deck & Long_aft deck & WD $(\mathrm{m})$ & Length $(\mathrm{m})$ & Recovery $(\%)$ \\
\hline SWERUS-L2-2-PC1 & $72^{\circ} 30.001^{\prime}$ & $175^{\circ} 19.170^{\prime} \mathrm{W}$ & 57 & 8.24 & 83.6 \\
SWERUS-L2-4-PC1 & $72^{\circ} 50.3447^{\prime}$ & $175^{\circ} 43.6383^{\prime} \mathrm{W}$ & 119.7 & 6.13 & 68 \\
SWERUS-L2-4-MC1 & $72^{\circ} 52.65^{\prime}$ & $175^{\circ} 42.648^{\prime} \mathrm{W}$ & 123.6 & 0.1 & $\mathrm{n} / \mathrm{a}$ \\
SWERUS-L2-5-GC1 & $72^{\circ} 52.1769^{\prime}$ & $176^{\circ} 12.4630^{\prime} \mathrm{W}$ & 115.5 & 1.43 & 48 \\
SWERUS-L2-20-GC1 & $77^{\circ} 21.5370^{\prime}$ & $163^{\circ} 02.0226^{\prime} \mathrm{E}$ & 115 & 0.83 & 14 \\
SWERUS-L2-22-PC1 & $78^{\circ} 13.3728^{\prime}$ & $164^{\circ} 27.7194^{\prime} \mathrm{E}$ & 364 & 6.45 & 72 \\
SWERUS-L2-23-GC1 & $78^{\circ} 39.6556^{\prime}$ & $165^{\circ} 00.9492^{\prime} \mathrm{E}$ & 508 & 4.06 & 68 \\
SWERUS-L2-24-GC1 & $78^{\circ} 47.81544^{\prime}$ & $165^{\circ} 21.9861^{\prime} \mathrm{E}$ & 964 & 4.05 & 68 \\
\hline
\end{tabular}

Our initial working hypothesis is that the regional sea level record from the East Siberian margin would exhibit behavior like that expected in "peripheral bulge" areas located 1000$3000 \mathrm{~km}$ from the centers of LGM ice sheets. These would include areas like the mid-Atlantic region of eastern North America (Cronin et al., 2007) and Europe (Lambeck et al., 2011; Steffen and $\mathrm{Wu}, 2011)$ that were isostatically uplifted during peak glaciation and subsequently subsided in a collapsing forebulge. However, the western Arctic Ocean and the adjacent Siberian margin are relatively poorly known in terms of both regional sea level and glacial history (Klemann et al., 2015). It is especially important to investigate the SLR history of this region in light of recent submarine geophysical and sediment core evidence for extensive ice shelf and iceberg scouring during glacial periods in Marine Isotope Stage (MIS) 6, 4, and 2. Submarine evidence comes from across much of the Arctic Ocean, including the Hovgaard RidgeArctic Ocean (Arndt et al., 2014), the Beaufort Sea (Engels et al., 2008), the Chukchi Sea (Polyak et al., 2007; Dove et al., 2014) and East Siberian Sea (Niessen et al., 2013) margins, Lomonosov Ridge, the Arlis Plateau, and the slope off Herald Canyon in the East Siberian Sea (Jakobsson et al., 2010, 2016). These new glacial discoveries suggest the need for a reevaluation of basic assumptions that underpin sea level reconstructions based on geophysical models, marine planktic and benthic oxygen isotopes, and coral reefs.

In addition, although studies of deglacial sediments using micropaleontological proxies are common throughout the Arctic and subarctic regions, most studied cores are from water depths deeper than $200 \mathrm{~m}$ (Ishman et al., 1996; Scott et al., 2009; Taldenkova et al., 2013; Carbonara et al., 2016; Hald, 1999; Osterman et al., 2002; Jennings et al., 2014; Wollenburg et al., 2007; Knudsen et al., 2004). The proxies provide excellent paleoceanographic records of water mass history but not direct evidence for the elevation and location of paleoshorelines. One exception is the study by Rasmussen and Thomsen (2014, see also Hald et al., 2004) of Storfjorden, Svalbard that demonstrates the sensitivity of foraminiferal species to rapid deglacial and Holocene climate changes in a previously glaciated area. Unlike the Svalbard region, the East Siberian margin did not host a large LGM ice sheet
(Svendsen et al., 2004; Jakobsson et al., 2014), but instead was located some distance from the Fennoscandian Ice Sheet and North American ice sheets (Peltier et al., 2015; Klemann et al., 2015). Thus, at least for much of the Younger Dryas and post-Younger Dryas intervals (12.8-10.7 ka), results presented here provide insight not only into Arctic sea level and glacial history and GIA models, but also extra-Arctic sea level records used to estimate global sea level patterns.

\section{Material and methods}

This study is a result of the 2014 SWERUS-C3 expedition (Swedish-Russian-US Arctic Ocean Investigation of climate-cryosphere-carbon interactions) to the Chukchi Sea, Herald Canyon, the East Siberian Sea margin, and the southern and central Lomonosov Ridge. The results are derived from ship-based and post-cruise, shore-based analyses of the stratigraphy, physical properties, chronology, and micropaleontology of sediment cores taken along two transects in the Chukchi Sea and East Siberian Sea across the outer continental shelf and upper continental slope.

\subsection{Stratigraphy and physical properties}

Cores SWERUS-L2-4-PC1 and 4-MC (4-PC1, 4-MC; $72^{\circ} 50.3447^{\prime} \mathrm{N}, 175^{\circ} 43.6383^{\prime} \mathrm{W}$ ) were part of a continental shelf and upper continental slope transect from the Herald Canyon region of the Chukchi Sea designed to recover Holocene and pre-Holocene deglacial sediments (Table 1, Fig. 1). The sediment bulk density and magnetic susceptibility (MS; Fig. 2) for the Herald Canyon transect clearly show a downcore increase in both MS and density in core 4-PC1 beginning at about $380 \mathrm{~cm}$ of core depth and in 5$\mathrm{GC} 1$ at $\sim 80 \mathrm{~cm}$ (Fig. 2). Core SWERUS-L2-2-PC1 (2-PC1; $77^{\circ} 21.5370^{\prime} \mathrm{N}, 163^{\circ} 02.0226^{\prime} \mathrm{E}$ ) from $57 \mathrm{~m}$ b.s.l. on the shelf recovered Holocene sediments with a maximum age of $4.2 \mathrm{ka}$ (Pearce et al., 2017). The focus of the current study is the interval in core 4-PC1 between 350 and $602 \mathrm{~cm}$ of core depth and from 90 to $120 \mathrm{~cm}$ in core 5-GC1, which both record the late deglacial regional SLR during and following the Younger Dryas. Multicore 4-MC was used to identify late Holocene 


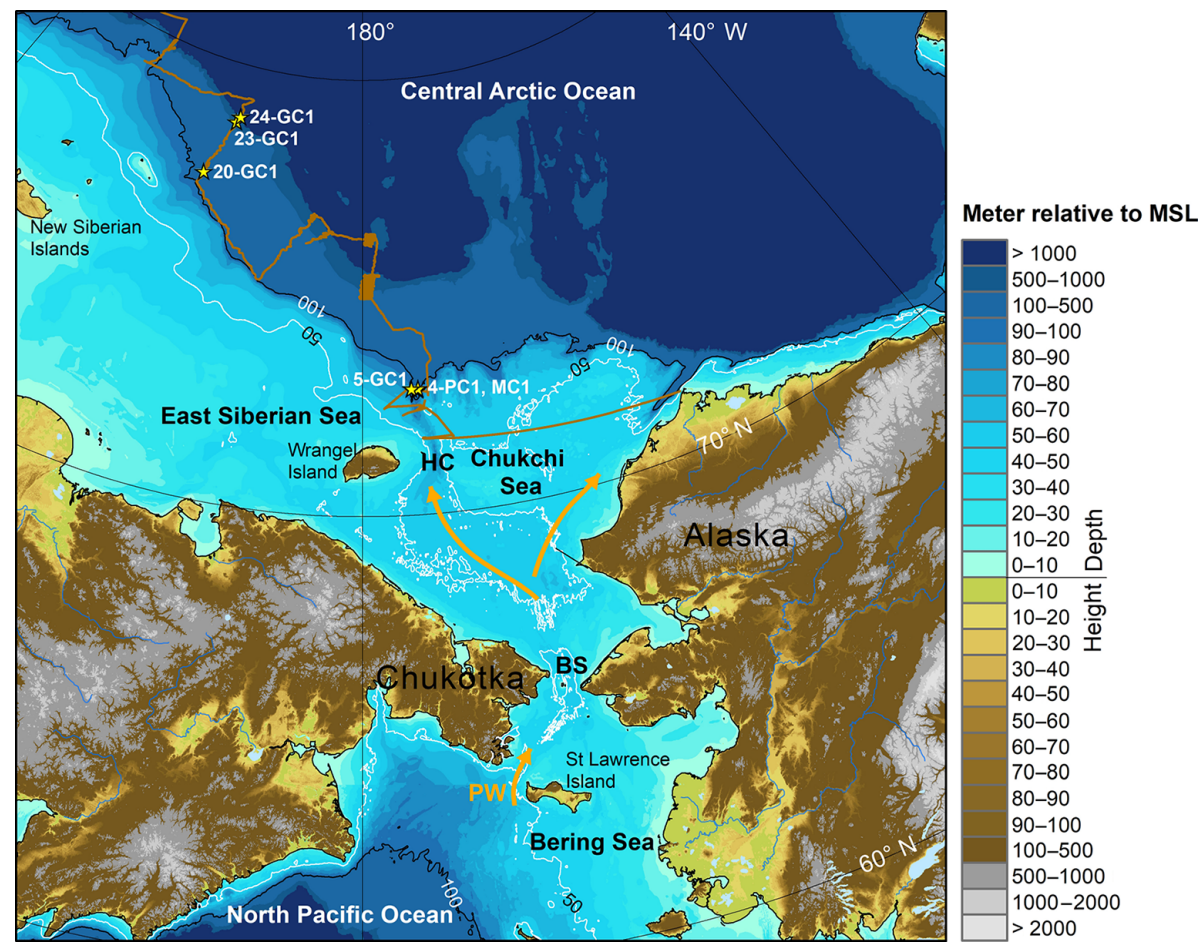

Figure 1. Map showing the approximate cruise tract of the SWERUS Leg 22014 expedition and the locations of cores SWERUS-L2-4-PC1 and SWERUS-L2-20-GC1 used in this study. Details on the cores can be found in Table 1.

microfaunal assemblages, which were distinct from those deposited during the late postglacial interval.

The East Siberian Sea transect included four cores from 115 to 964 m b.s.l. (Fig. 3). Our focus was on samples from the core catcher in core $20-\mathrm{GC} 1$ about $56-81 \mathrm{~cm}$ below the seafloor, which recorded a transitional unit with increasing MS and density downcore, similar to the trend seen in core 4-PC1. The chirp sonar profile crossing the coring site of 4-PC1 reveals acoustic characteristics suggesting that denser, coarser-grained postglacial sediments may have prevented further penetration and core recovery (Jakobsson et al., 2017). This is also likely for the 5-GC1 and 20-GC1 sites. As discussed below, radiocarbon dating confirms that transitional units at both Herald Canyon and the East Siberian Sea margin represent nearly coeval late deglacial sediments deposited during sea level transgression. The other three cores in the East Siberian Sea transect were taken from water depths that are too deep to observe a sedimentological or micropaleontological signal of regional sea level.

\subsection{Micropaleontology}

Benthic foraminifera (Edwards and Wright, 2015) and ostracodes (Cronin, 2015) are among the more useful groups for reconstructing paleo-sea level records due to the restricted environmental preferences of many species. The benthic foraminifera and ostracodes from cores 4-PC1, 4-MC, 5-GC1, and 20-GC1 were studied in order to reconstruct paleoenvironmental conditions and specifically to estimate paleodepth ranges from key indicator species. The working halves of the sediment cores were sampled shipboard using $20 \mathrm{~cm}^{3}$ plastic scoops. Bulk sediment samples were sealed in labeled plastic bags and stored refrigerated. Samples were processed shipboard to assess microfossil preservation and to target productive intervals, which were later sampled at Stockholm University in 2015. All samples were washed through a $63 \mu \mathrm{m}$ sieve using a light-diffusive pressure stream to disaggregate the sediment and collect the sand size fraction. The remaining coarse fraction was rinsed and decanted out of the sieve using distilled water from a squirt bottle onto labeled filter paper, then dried in the oven at $\leq 50^{\circ} \mathrm{C}$ for a minimum of $5 \mathrm{~h}$. Sediment was stored in $15 \mathrm{~mL}$ snap-cap glass vials, and detailed micropaleontological studies of benthic foraminifera and ostracodes were conducted at the US Geological Survey (USGS) in Reston, Virginia.

The following literature sources on Arctic Ocean foraminiferal taxonomy and ecology were used: Wollenburg and Mackensen (1998), Polyak et al. (2002), Scott et al. (2008), and McDougall (1994). The most useful publication on shallow-water Arctic foraminiferal species ecology is Polyak et al. (2002), which we used as a primary source of key indicator species for inner shelf, river-influenced environments. The river-proximal assemblage of Polyak et al. (2002) from the southern Kara Sea was critical for indicating modern analog assemblages for nearshore, brackish-water 


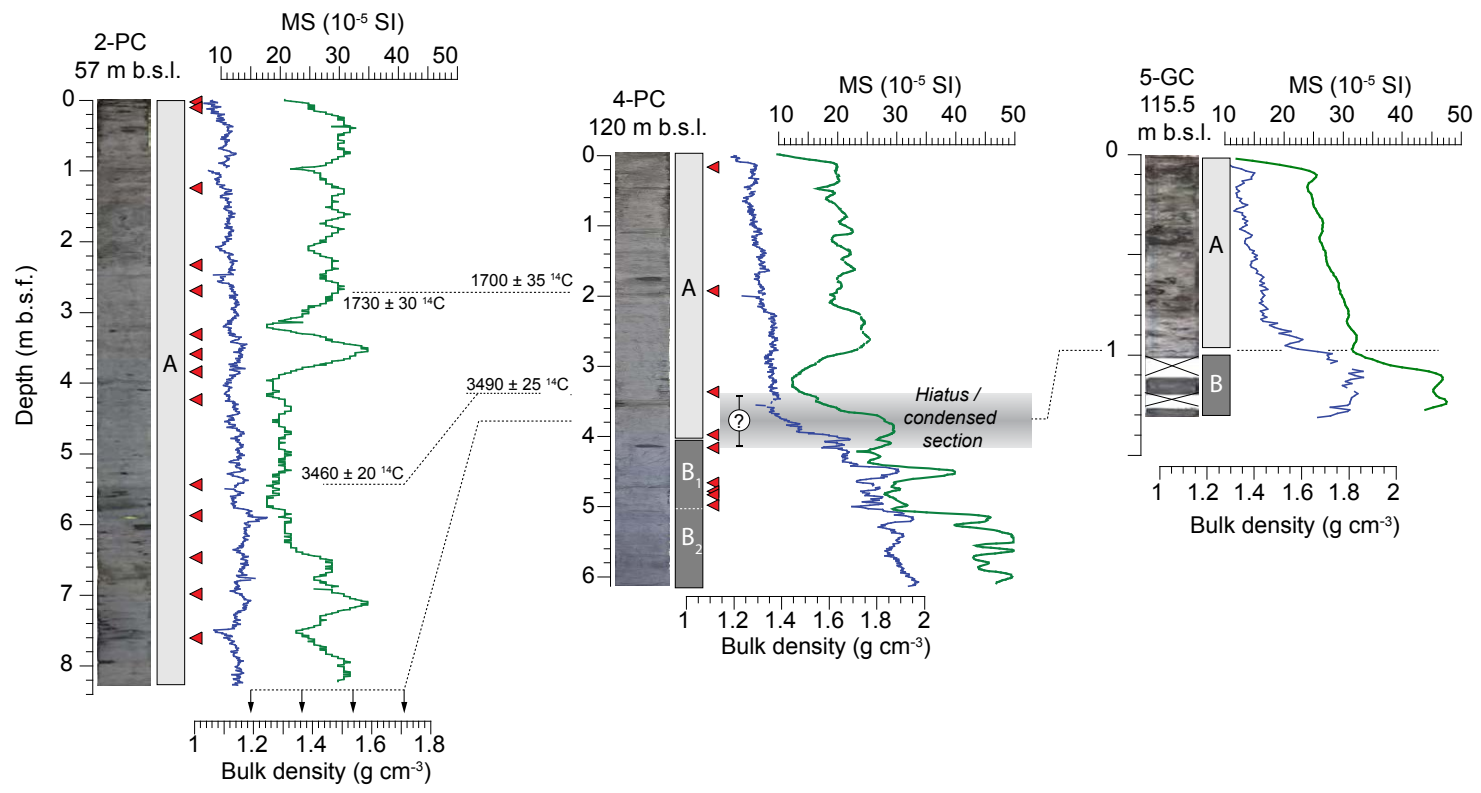

Figure 2. Transect of Herald Canyon cores SWERUS-L2-2-PC1, 4-PC1, and 5-GC showing core photographs, lithologic units A and B, radiocarbon age control (red diamonds), magnetic susceptibility, and bulk density. Further details on the age model of core 2-PC1 can be found in Pearce et al. (2017), and additional details on the lithology of 2-PC and 4-PC are in Jakobsson et al. (2017).

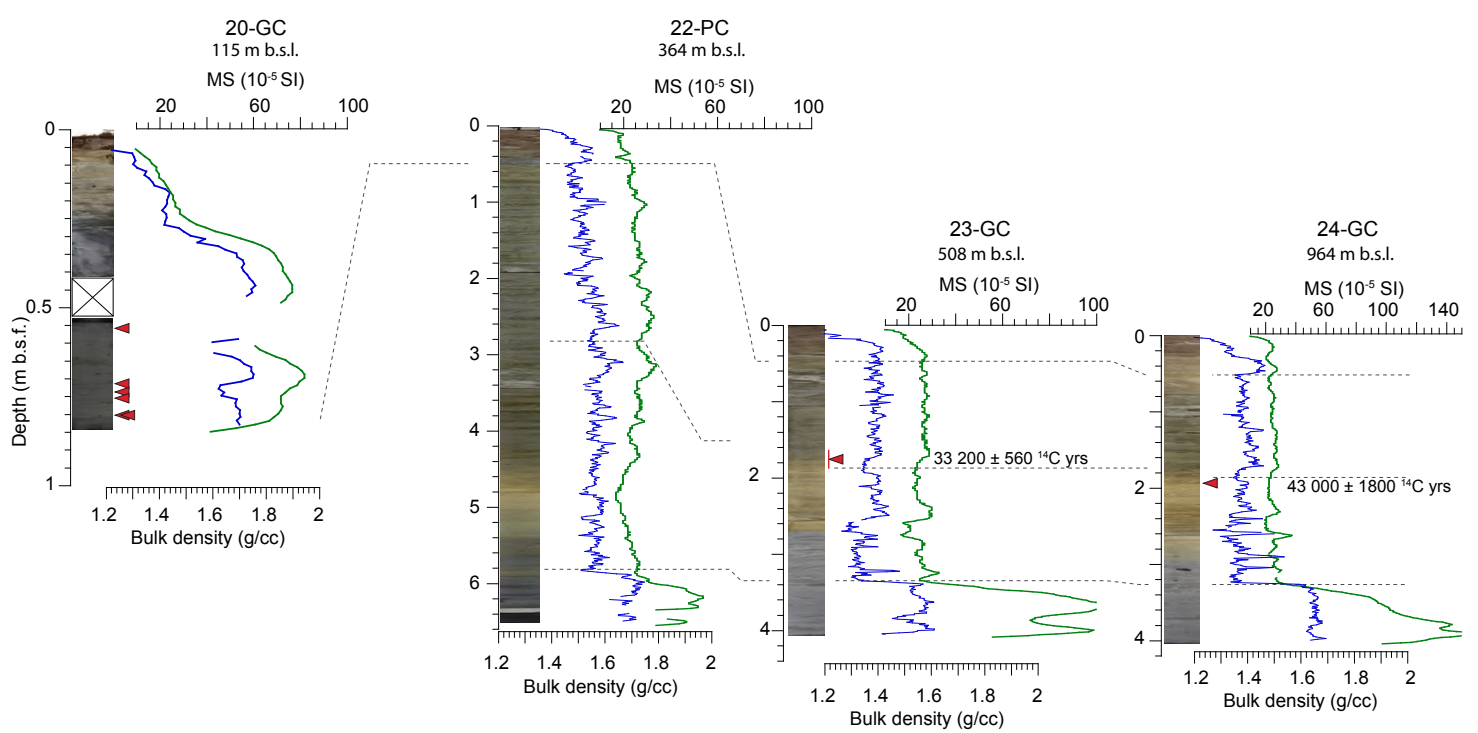

Figure 3. Transect of the East Siberian Sea cores SWERUS-L2-20-GC, 22-PC, 23-GC, and 24-GC crossing the shallow shelf (20-GC) and the slope of the East Siberian Sea (22-PC, 23-GC, 24-GC) showing core photos, radiocarbon date locations, magnetic susceptibility, and bulk density. Radiocarbon dates indicate that the deglacial, dense, high-susceptibility, dark gray sediments recovered in the lower half of 20-GC are not correlative to a similar lithology at the base of 22-PC, 23-GC, and 24-GC, which predate the LGM. They are potentially correlative to a thin, higher-susceptibility, and dense gray sediment layer found in the upper $50 \mathrm{~cm}$ of the slope cores.

environments influenced by freshwater river influx from the $\mathrm{Ob}$ and Yenisei rivers. Korsun and Hald (1998), Wollenburg and Kuhnt (2000), and Osterman et al. (1999) were also consulted and provided complementary ecological data from other regions of the Arctic Ocean.
The primary sources of ostracode taxonomy and ecology were Stepanova (2006), Yasuhara et al. (2014), and Gemery et al. (2015) and the references therein. The study by Gemery et al. (2015) gives the modern depth range and ecological data for 1340 modern surface samples from the Arctic and subarctic seas. Simple statistical analyses were used to obtain 

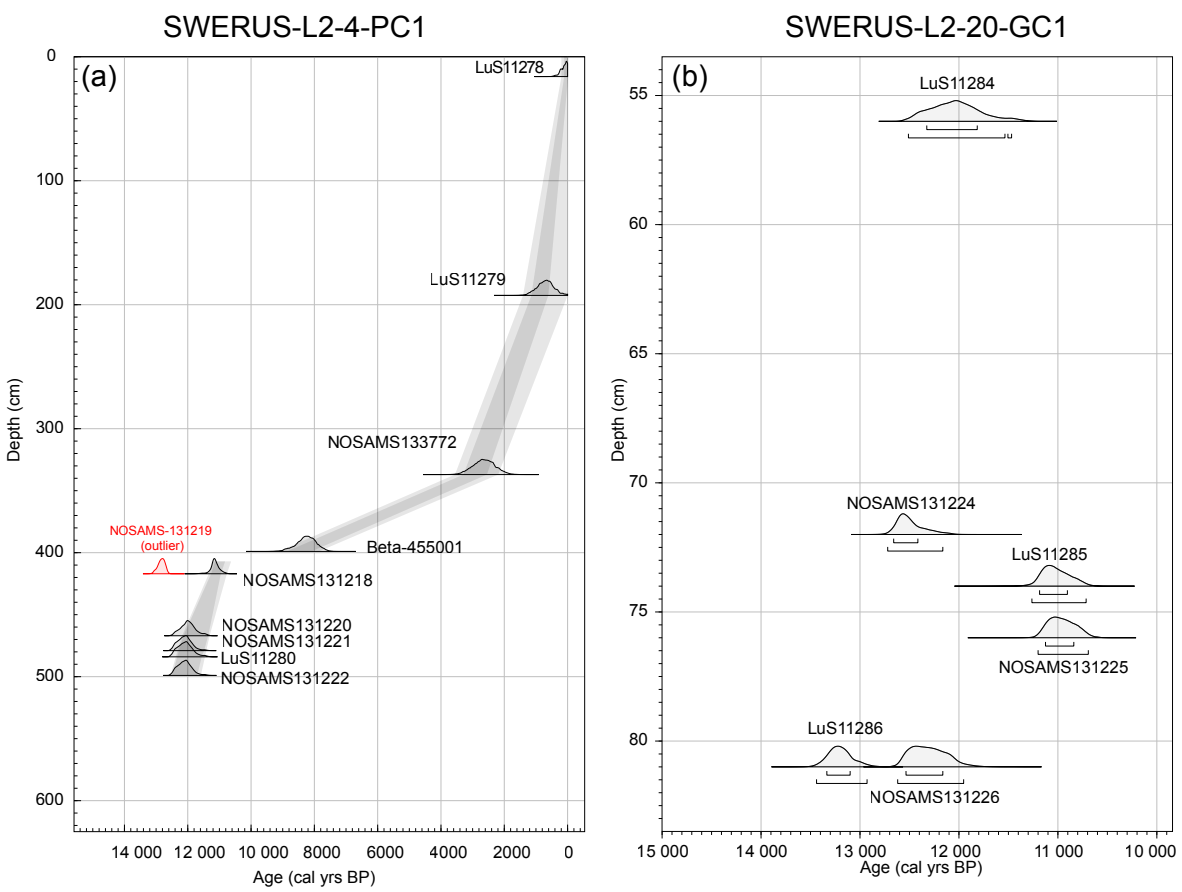

Figure 4. (a) Radiocarbon corrected age model for core SWERUS-L2-4-PC1 showing unconformity at about $400 \mathrm{~cm}$ of core depth. Note that no dates are available lower than $500 \mathrm{~cm}$ of core depth; see text for discussion of this age uncertainty. (b) Radiocarbon corrected age model for core SWERUS-L2-20-GC1. Reworking is suspected for the outlier NOSAMS131224.

the most reasonable paleodepth estimates from fossil biofacies on the basis of modern ecology and the modern depth ranges of key species.

\subsection{Radiocarbon chronology}

From core SWERUS-L2 samples containing the planktonic foraminifera Neogloboquadrina pachyderma, mixed benthic foraminifera or mollusc shells (identified by A. Gukov) were picked shipboard for accelerator mass spectrometry (AMS) radiocarbon measurements upon return. Further radiocarbon sampling was conducted at Stockholm University and the USGS in Reston, Virginia and ages were obtained from the National Ocean Sciences Accelerator Mass Spectrometry (NOSAMS) facility at the Woods Hole Oceanographic Institution in Woods Hole, Massachusetts and from the Radiocarbon Dating Laboratory at Lund University and Beta Analytic.

The chronology of core SWERUS-L2-4-PC1 is based on 10 AMS radiocarbon ages, including one outlier (Fig. 4) presented and discussed in Jakobsson et al. (2017). On the basis of a major change in the physical properties and geochemical composition of the core (Fig. 2), a key lithologic transition from $\sim 413$ to $400 \mathrm{~cm}$ of depth was identified that includes a hiatus or condensed section. All ages are calibrated with the Marine13 calibration curve (Reimer et al., 2013) using the age depth modeling software Oxcal 4.2 (Bronk Ramsey, 2008, 2009). Two different values are used for the lo- cal marine radiocarbon reservoir correction. In the lower part of the core up to approximately $400 \mathrm{~cm}$, analyses of sediment chemical and physical properties suggest that there is no connection to the Pacific Ocean and thus no inflow of relatively old Pacific waters (Jakobsson et al., 2017). For this lower section, $\Delta R=50 \pm 100$ years was applied on the basis of present values in the Laptev Sea (Bauch et al., 2001), which is the closest site with information on the modern reservoir age from a shallow Arctic shelf setting with little or no Pacific influence (Reimer and Reimer, 2001). In the upper $400 \mathrm{~cm}$ of the core, which represent the late Holocene, a larger reservoir was expected due to the Pacific influence and $\Delta R=300 \pm 200$ years was applied to the radiocarbon ages in this section. This value is lower than the 477 years derived for neighboring core 2-PC1 (Pearce et al., 2017) because of the significantly greater water depth of the site. Below $100 \mathrm{~m}$ of water depth, Atlantic-sourced waters are present in Herald Canyon and these waters have a lower radiocarbon reservoir age. Six radiocarbon ages were also obtained from the core catcher of core 20-GC1, and one each was obtained from 23CG1 and 24-GC1 and are given in Table 2 (see Fig. 4). 
Table 2. Radiocarbon ages calibrated from SWERUS-C3 Leg 2, 4-PC, 20-GC, 23-GC, and 24-GC.

\begin{tabular}{|c|c|c|c|c|c|c|c|c|c|c|c|c|c|}
\hline Core & Lab ID & $\begin{array}{l}\text { Mid-core } \\
\text { depth }(\mathrm{cm})\end{array}$ & Material dated & $\begin{array}{l}\text { C14 age } \\
\text { (yrs BP) }\end{array}$ & Error & $\Delta R$ & $\begin{array}{l}\text { Cal. unmodel } \\
2 \sigma \text { from } \\
\text { (cal yrs BP) }\end{array}$ & $\begin{array}{l}\text { Cal. unmodel } \\
2 \sigma \text { to } \\
\text { (cal yrs BP) }\end{array}$ & $\begin{array}{l}\text { Cal. unmodel } \\
2 \sigma \text { mean }\end{array}$ & error & $\begin{array}{l}\text { Modeled } \\
\text { age median }\end{array}$ & $\begin{array}{l}\text { Modeled } \\
\text { age mean }\end{array}$ & error \\
\hline $\begin{array}{l}\text { 4-PC1, }, \\
15-17 \mathrm{~cm}\end{array}$ & LuS11278 & 16 & $\begin{array}{l}\text { Mollusc: } \\
\text { Nuculana } \\
\text { pernula }\end{array}$ & 445 & 35 & $\begin{array}{l}300 \pm \\
200\end{array}$ & 225 & $\ldots$ & 65 & 54 & 51 & 105 & 79 \\
\hline $\begin{array}{l}\text { 4-PC1, 2, } \\
141-142 \mathrm{~cm}\end{array}$ & LuS11279 & 192.5 & $\begin{array}{l}\text { Mollusc: } \\
\text { Yoldia amyg- } \\
\text { dala } \\
\text { borea }\end{array}$ & 1700 & 35 & $\begin{array}{l}300 \pm \\
200\end{array}$ & 1180 & 720 & 954 & 117 & 952 & 1236 & 166 \\
\hline $\begin{array}{l}4 \mathrm{PC} 1,3, \\
135-137 \mathrm{~cm}\end{array}$ & NOSAMS133772 & 337 & Mollusc & 3490 & 25 & $\begin{array}{l}300 \pm \\
200\end{array}$ & 3254 & 2749 & 3003 & 131 & 2998 & 2835 & 243 \\
\hline $\begin{array}{l}\text { 4-PC1, 4, } \\
65-67 \mathrm{~cm}\end{array}$ & NOSAMS131218 & 417 & Mollusc & 10200 & 30 & $\begin{array}{l}50 \pm \\
100\end{array}$ & 11429 & 10788 & 11139 & 146 & 11143 & 11112 & 147 \\
\hline $\begin{array}{l}\text { 4-PC1, 4, } \\
65-67 \mathrm{~cm}\end{array}$ & NOSAMS131219 & 417 & Mollusc & 11400 & 35 & $\begin{array}{l}50 \pm \\
100\end{array}$ & 13070 & 12635 & 12834 & 112 & 12826 & Outlier & - \\
\hline $\begin{array}{l}4-\mathrm{PC} 1,4, \\
115-117 \mathrm{~cm}\end{array}$ & NOSAMS 131220 & 467 & Mollusc & 10700 & 30 & $\begin{array}{l}50 \pm \\
100\end{array}$ & 12454 & 11465 & 11987 & 237 & 11994 & 11870 & 268 \\
\hline $\begin{array}{l}\text { 4-PC1, 5, } \\
5-7 \mathrm{~cm}\end{array}$ & NOSAMS131221 & 479 & Mollusc & 10750 & 30 & $\begin{array}{l}50 \pm \\
100\end{array}$ & 12520 & 11670 & 12095 & 220 & 12101 & 11964 & 264 \\
\hline $\begin{array}{l}4-\mathrm{PC} 1,5, \\
10-12 \mathrm{~cm}\end{array}$ & LuS11280 & 484 & $\begin{array}{l}\text { Mollusc: } \\
\text { Yoldia amyg- } \\
\text { dala } \\
\text { borea }\end{array}$ & 10745 & 55 & $\begin{array}{l}50 \pm \\
100\end{array}$ & 12539 & 11602 & 12078 & 238 & 12088 & 11993 & 264 \\
\hline $\begin{array}{l}\text { 4-PC1, 5, } \\
25.27 \mathrm{~cm}\end{array}$ & NOSAMS 131222 & 499 & Mollusc & 10750 & 35 & $\begin{array}{l}50 \pm \\
100\end{array}$ & 12525 & 11661 & 12094 & 222 & 12100 & 12079 & 267 \\
\hline $\begin{array}{l}20-\mathrm{GC} 1, \\
\mathrm{CC}, 2-4 \mathrm{~cm}\end{array}$ & LuS11284 & 56 & $\begin{array}{l}\text { Mixed benthic } \\
\text { foraminifera: } \\
\text { Elphidium } \\
\text { spp., Pyrgo } \\
\text { sp., Islandiella } \\
\text { teretis }\end{array}$ & 10725 & 65 & $\begin{array}{l}50 \pm \\
100\end{array}$ & 12511 & 11468 & 12034 & 254 & 12044 & & \\
\hline $\begin{array}{l}20-\mathrm{GC} 1, \\
\mathrm{CC}, \\
18-20 \mathrm{~cm}\end{array}$ & NOSAMS131224 & 72 & Mollusc & 11050 & 30 & $\begin{array}{l}50 \pm \\
100\end{array}$ & 12720 & 12163 & 12490 & 142 & 12521 & & \\
\hline $\begin{array}{l}20-\mathrm{GC} 1, \\
\mathrm{CC}, \\
20-22 \mathrm{~cm}\end{array}$ & LuS11285 & 74 & $\begin{array}{l}\text { Mollusc: } \\
\text { Macoma sp. }\end{array}$ & 10110 & 55 & $\begin{array}{l}50 \pm \\
100\end{array}$ & 11263 & 10715 & 11020 & 145 & 11034 & & \\
\hline $\begin{array}{l}20-\mathrm{GC} 1, \\
\mathrm{CC}, \\
22-24 \mathrm{~cm}\end{array}$ & NOSAMS131225 & 76 & Mollusc & 10050 & 40 & $\begin{array}{l}50 \pm \\
100\end{array}$ & 11200 & 10693 & 10958 & 136 & 10968 & & \\
\hline $\begin{array}{l}20-\mathrm{GC} 1, \\
\mathrm{CC}, \\
27-29 \mathrm{~cm}\end{array}$ & LuS11286 & 81 & $\begin{array}{l}\text { Mollusc: } \\
\text { Macoma sp. }\end{array}$ & 11785 & 65 & $\begin{array}{l}50 \pm \\
100\end{array}$ & 13439 & 12929 & 13200 & 126 & 13209 & & \\
\hline $\begin{array}{l}20-\mathrm{GC} 1, \\
\mathrm{CC}, \\
27-29 \mathrm{~cm}\end{array}$ & NOSAMS131226 & 81 & Mollusc & 10900 & 60 & $\begin{array}{l}50 \pm \\
100\end{array}$ & 12619 & 11953 & 12302 & 182 & 12318 & & \\
\hline $\begin{array}{l}23-\mathrm{GCl}, \quad 2, \\
62-79 \mathrm{~cm}\end{array}$ & Lu131228 & $169-186$ & Mollusc & 33200 & 560 & & & & & & & & \\
\hline $\begin{array}{l}23-G C 1, \quad 2, \\
87-89 \mathrm{~cm}\end{array}$ & Lu131229 & 192 & $\begin{array}{l}\text { Foraminifera, } \\
\text { planktic } N . \\
\text { pachyderma }\end{array}$ & 43000 & 1800 & & & & & & & & \\
\hline
\end{tabular}

\section{Results}

\subsection{Herald Canyon}

\subsubsection{Age model}

The age of the base of the core at $609 \mathrm{~cm}$ of composite depth is estimated to be approximately $13.5 \mathrm{ka}$, although this is based on extrapolation beyond the lowermost date at $499 \mathrm{~cm}$ (see discussion below). This implies that much of the Younger Dryas stadial ( 12.9-11.7 ka; Steffensen et al., 2008 ) is captured in core 4-PC1 between approximately 460 and $560 \mathrm{~cm}$ of depth. The lower section of core 4-PC1 is characterized by a nearly uniform high sediment accumulation rate of about $85 \mathrm{~cm} \mathrm{ka}^{-1}$ based on dated levels between 417 and $499 \mathrm{~cm}$, yielding ages around $11100-12100 \mathrm{ka}$ (Fig. 4). The age of the midpoint of the transition between the lower and upper lithological units at $407 \mathrm{~cm}$ is estimated to $(1 \sigma$ age range) $10787-11209 \mathrm{cal}$ yrs BP. Jakobsson et al. (2017) refer to the upper and lower units of core 4-PC1 as units $\mathrm{A}$ and $\mathrm{B}$, respectively. The transition between the two units was defined based on measured $\delta^{13} \mathrm{C}_{\text {org }}$ in the sediments (Jakobsson et al., 2017). The age range was determined using $\Delta R=50$ 


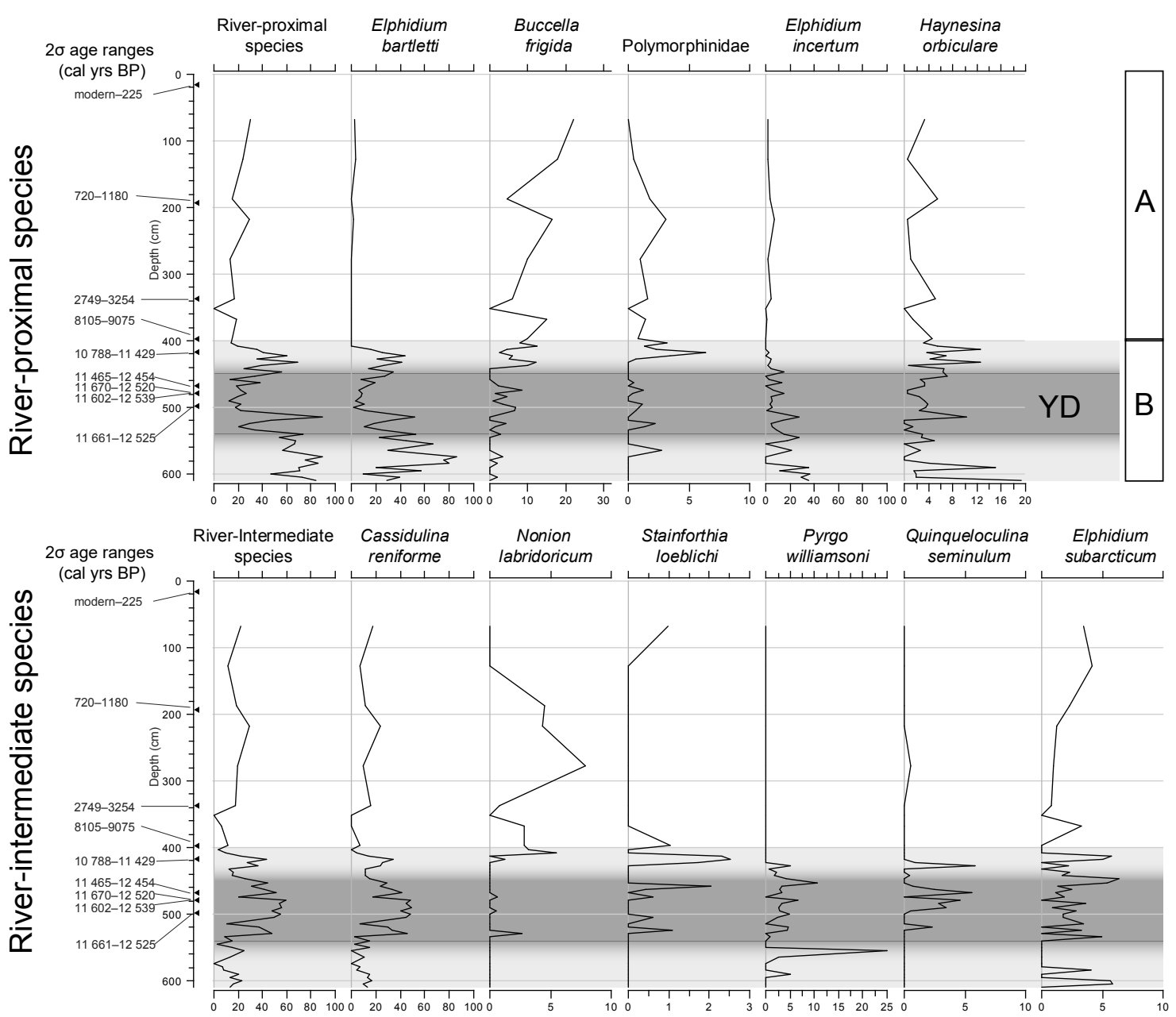

Figure 5. The distribution of benthic foraminifers in the SWERUS-L2-4-PC1 core showing species percent abundance and depth of the samples in the core. The upper panel shows river-proximal species, and the lower panel shows river-intermediate species. Ecological classification for species groups is from Polyak et al. (2002). In the river-proximal species group, Elphidium bartletti is common. In the river-intermediate species group, Cassidulina reniforme is dominant. Shading estimates the boundary between the late deglacial (Younger Dryas, Preboreal) and the Holocene intervals. See also Fig. 7. Stratigraphic units A and B are based on multiple criteria and discussed in the text and in Jakobsson et al. (2017).

and upcore extrapolation of the youngest age at $417 \mathrm{~cm}$ of depth. The upper unit A of core 4-PC1 extends to present day. The oldest dated level in unit $\mathrm{A}$ is at $399 \mathrm{~cm}$ where a $1 \sigma$ age range of $8332-8805$ cal yrs BP was acquired from dating unidentified organic material. An age model was not developed for individual samples in core 20-GC; however, the micropaleontological data are discussed below.

\subsubsection{Micropaleontology}

Figure 5 shows the river-proximal and river-intermediate foraminiferal species from core 4-PC1 in the upper and lower panels, respectively. The most noteworthy feature of the preYounger Dryas to early Younger Dryas interval is the dominance of river-proximal species (Elphidium bartletti, Haynesina orbiculare) below $510 \mathrm{~cm}$. The subsequent decrease in this assemblage is coincident with an increase to $40-50 \%$ in river-intermediate species, such as Cassidulina reniforme, Pyrgo williamsoni, and Quinqueloculina seminulum (Fig. 5; Appendix). This transition is somewhat abrupt, beginning at $\sim 520 \mathrm{~cm}$ of core depth and possibly marking the onset of the Younger Dryas. River-intermediate species remained common in the interval at $520-400 \mathrm{~cm}$ of core 4-PC1; however, it is noteworthy that there are still significant proportions of river-proximal species. We emphasize that species from both river-proximal and river-intermediate biofacies are often found living together. It is prudent therefore to interpret the significance of these oscillations in the two biofacies within unit B cautiously.

The age of the key transition between 413 and $400 \mathrm{~cm}$ of core depth is estimated to be about $11 \mathrm{ka}$ (Jakobsson et al., 2017). Sedimentation above this transition increased at this 
(a)

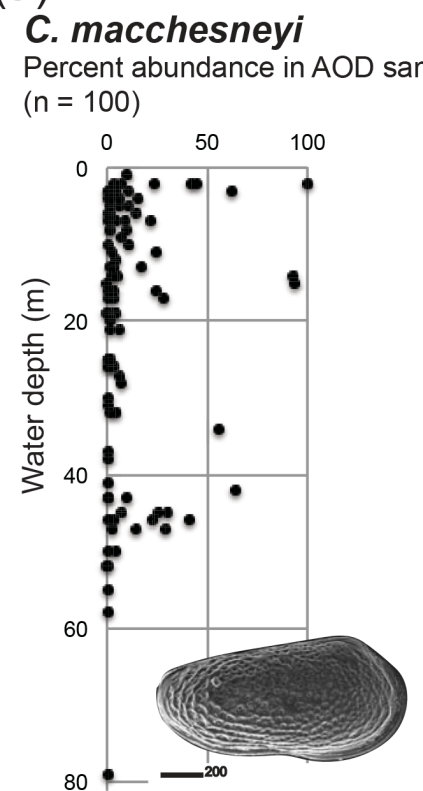

(b)

P. pseudopunctillata

$(n=233)$

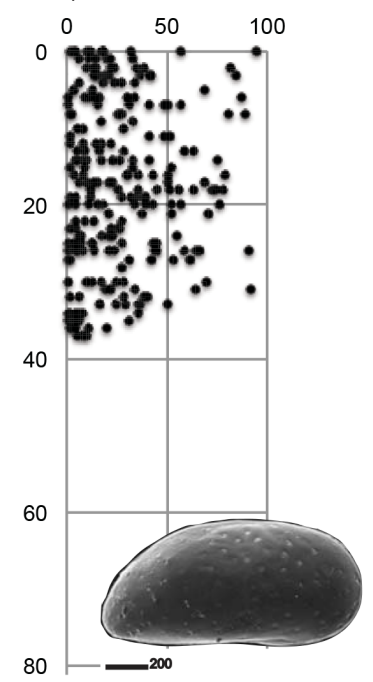

(c)

\section{H. sorbyana}

Percent abundance in AOD sample $(n=329)$

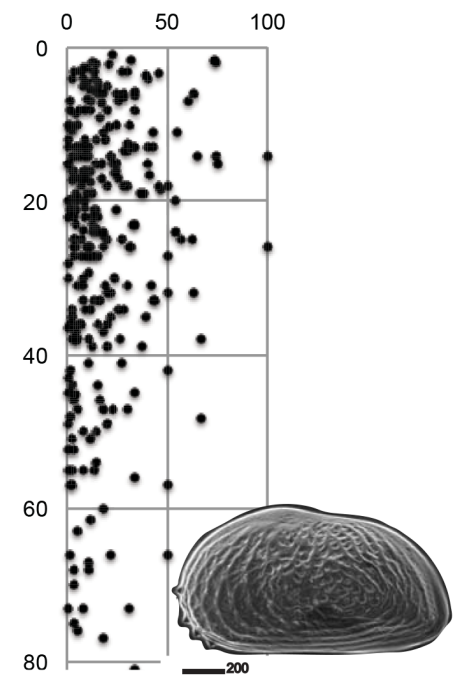

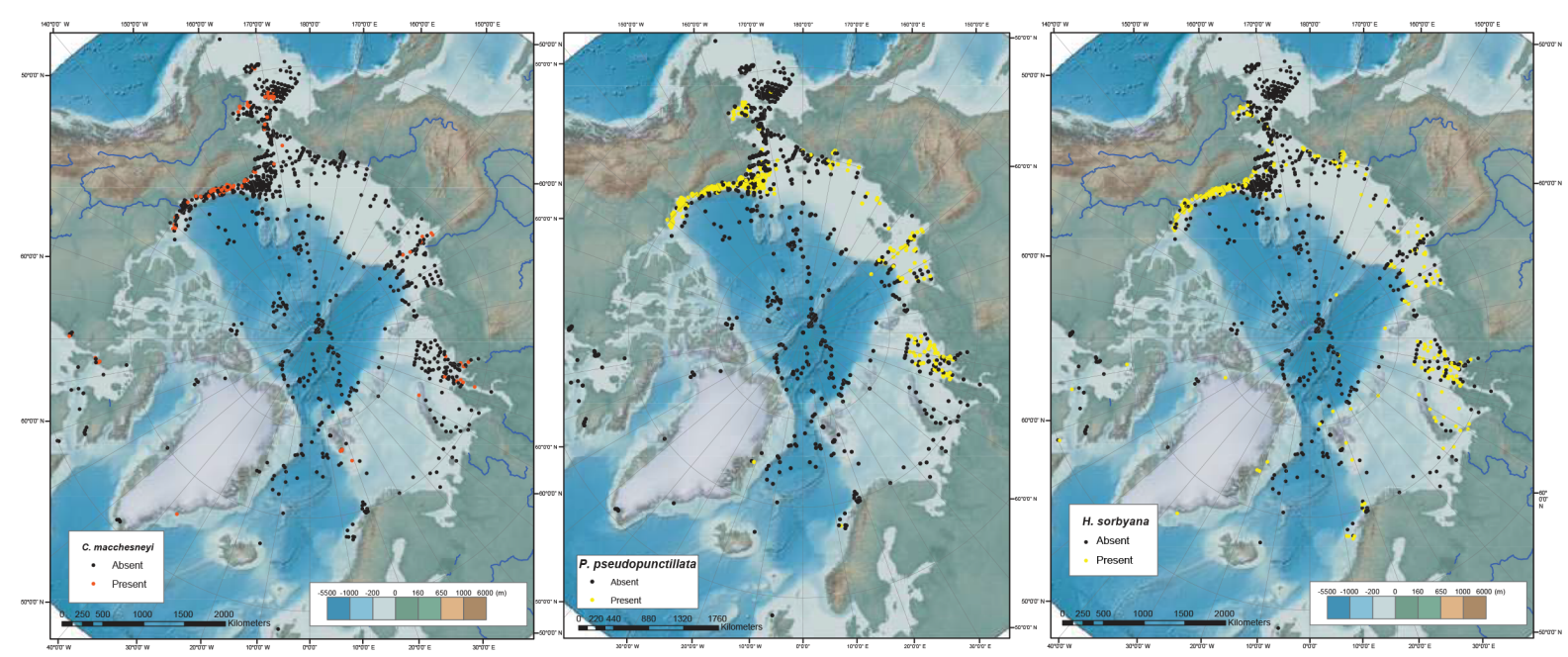

Figure 6. The ostracodes (a) Cytheromorpha macchesneyi, (b) Paracyprideis pseudopunctillata, and (c) Heterocyprideis sorbyana (from 4-PC1) are plotted showing the percent abundance of each species at modern depths based on the 1200-sample modern Arctic Ostracode Database (AOD; Gemery et al., 2015). Only modern AOD samples with $>50$ total ostracode specimens were used. Rabilimis (not shown) is also a marginal marine indicator species found in core $20-\mathrm{GC} 1$.

site during the Holocene (Fig. 4). Although the Holocene is not the main topic of our study, it is noteworthy that, like the ostracode assemblages discussed below, Holocene shelf foraminiferal faunas are dominated by fully marine, mid-toouter shelf species and contrast strongly with late deglacial assemblages dominated by species signifying riverine influence.

Analyses of benthic ostracode from core 4-PC1 yielded similar paleoenvironmental results; the modern geographic distributions and depth ranges of key species are shown in
Fig. 6 (Appendix). From the base of the core at 609 to $\sim 509 \mathrm{~cm}$ there are rare ostracodes, mainly Paracyprideis pseudopunctillata and Sarsicytheridea punctillata, which are both shallow nearshore species. From 504 to $427 \mathrm{~cm}$ there is an abundant and diverse assemblage including Cytheromorpha macchesneyi, Rabilimis sp., Cytheropteron spp., Acanthocythereis dunelmensis (mean modern depth of $16 \mathrm{~m}$ ), and Semicytherura complanata. C. macchesneyi and P. pseudopunctillata (mean modern depths of $18 \mathrm{~m}$ ) represent $\sim 23$ and $29 \%$ of $4-\mathrm{PC} 1$ assemblages from 500 to $460 \mathrm{~cm}$ of core 
depth, which is the interval containing river-intermediate foraminiferal assemblages. From 367 to $352 \mathrm{~cm}$ there were rare specimens of A. dunelmensis, Kotoracythere arctoborealis, and Cytheropteron spp. similar to Holocene shelf assemblages found in multicore 4-MC and in 2-PC1 from 57 MWD (meters water depth; Pearce et al., 2017). Thus, there is a faunal change from shallow-water, brackish assemblages to mid-shelf assemblages near the unconformity spanning the late deglacial-Holocene boundary.

Core 5-GC1 core catcher samples from $\sim 100$ to $125 \mathrm{~cm}$ of core depth contain a calcareous benthic assemblage with common specimens of $E$. bartletti and $H$. orbiculare, which are both river-proximal species found in the lowermost zone of 4-PC1. In contrast, samples from 15 to $75 \mathrm{~cm}$ of core depth contain typical Holocene shelf benthic foraminifers (mainly Elphidium excavatum clavata) and ostracodes (A. dunelmensis, Elofsonella concinna, Normanocythere leioderma, Cytheropteron spp.).

\subsection{East Siberian slope}

\subsubsection{Age model}

In core 20-GC1 (115 MWD), six AMS radiocarbon dates between 56 and $81 \mathrm{~cm}$ indicate ages between $\sim 13$ and $11 \mathrm{ka}$ (Fig. 4b, Table 2), and the average of the median ages of the six radiocarbon ages is $12.0 \mathrm{ka}$. This sequence contains several reversals in radiocarbon ages, and it is more likely for old material to be reworked and redeposited compared to the contamination of younger material into underlying sediments. The age of this unit therefore is probably around $11.0 \mathrm{ka}$ (the youngest series of dates in this core) with significant input of older, reworked material.

\subsubsection{Micropaleontology}

Microfaunas from this interval suggest deposition in a shallow nearshore environment. For example, the foraminifers Elphidium bartletti, Haynesina orbiculare, andElphidium incertum are river-proximal species in the Kara Sea (Polyak et al., 2002). The ostracodes Heterocyprideis sorbyana, Rabilimis sp., and Sarsicytheridea punctillata all tolerate reduced salinity near river mouths and estuaries. On the basis of modern species distributions (Gemery et al., 2015), the mean depth range for $H$. sorbyana is $14 \mathrm{~m}(n=90$; Fig. 6). In the Laptev and Kara seas, Rabilimis is found in modern samples of similar depths (Stepanova, 2006). These nearshore ostracode species are either absent or occur in low numbers at deeper sites in the Laptev and Kara seas.

\section{Discussion}

\subsection{LGM and deglacial sedimentation in the Arctic Ocean}

Before interpreting the East Siberian Sea and Chukchi Sea deglacial sea level chronology, it is useful to examine the broader patterns of LGM and deglacial sedimentation in the Arctic Ocean for context. Marine sediments deposited during the last glacial maximum are uncommon in the central Arctic Ocean due to the extensive sea ice and ice shelf cover. For example, Polyak et al. (2004) documented a hiatus between 19 and $13 \mathrm{ka}$ in several cores from the western Arctic. In a compilation of 199 new and published calibrated radiocarbon dates from the central Arctic Ocean, Poirier et al. (2012) found similar results: no dates at 21-22 ka, 4 total from 19 to $15 \mathrm{ka}, 4$ dates from 14 to $15 \mathrm{ka}, 5$ dates from 13 to $14 \mathrm{ka}$, and a spike up to 13 dates between 12 and $13 \mathrm{ka}$. Several studies of Arctic Ocean margins have recovered deglacial sediments. Taldenkova et al. (2013) found the earliest deglacial dates of 15.34 and $15.37 \mathrm{ka}$ in core PS51/154-11 at 270 MWD in the Laptev Sea. These correspond to the first appearance of common benthic foraminifera. Scott et al. (2009) dated sediments from piston core PC750 (1000 MWD) off the Mackenzie Trough on the Canadian margin at $11.3 \mathrm{cal} \mathrm{ka}$ at $180 \mathrm{~cm}$ and $13.3 \mathrm{ka}$ at $380 \mathrm{~cm}$. Benthic foraminifera first become common in core PS750 at $\sim 11.3 \mathrm{ka}$. In core PS2138-1 (995 MWD) from the Barents Sea slope north of Spitsbergen, Wollenburg et al. (2004; see also Matthiessen et al., 2001; Nørgaard-Pedersen, 2003) dated one of the more complete LGM deglacial sequences with nine calibrated radiocarbon ages from 23.88 to $15.52 \mathrm{ka}$ from 275 to $65 \mathrm{~cm}$ core depths. Unlike the Laptev, Siberian, and Canadian margins, relatively continuous sedimentation in the Barents Sea region during this period reflects complex changes in productivity and oceanography during Greenland Stadials GS-2 (21$14.6 \mathrm{ka})$ and GS-1 (14.6-11.6 ka, Bølling-Allerød, Younger Dryas) largely due to changes in inflowing warm Atlantic Water and the West Spitsbergen Current. In sum, these examples show that the earliest ages for deglacial sedimentation and preservation of abundant benthic microfaunas (and by inference productive marine ecosystems) varies along different Arctic Ocean margins. In regards to the undated interval in the 4-PC1 core from 609 to $500 \mathrm{~cm}$ of core depth, this means that, pending further investigations, we cannot completely exclude the possibility that the lowermost sediments below $500 \mathrm{~cm}$ of core depth in 4-PC1 are older than $\sim 13.5 \mathrm{ka}$.

\subsection{Comparison with other Arctic deglacial microfaunal records}

The results show a faunal similarity of diagnostic nearshore assemblages in East Siberian Sea cores taken on the outer shelf and upper slope (core 4-PC1 520-600 cm, core 5-GC $\sim 100-125 \mathrm{~cm}$, and core $20-\mathrm{GC} 1 \sim 56-81 \mathrm{~cm}$ ) that supports 


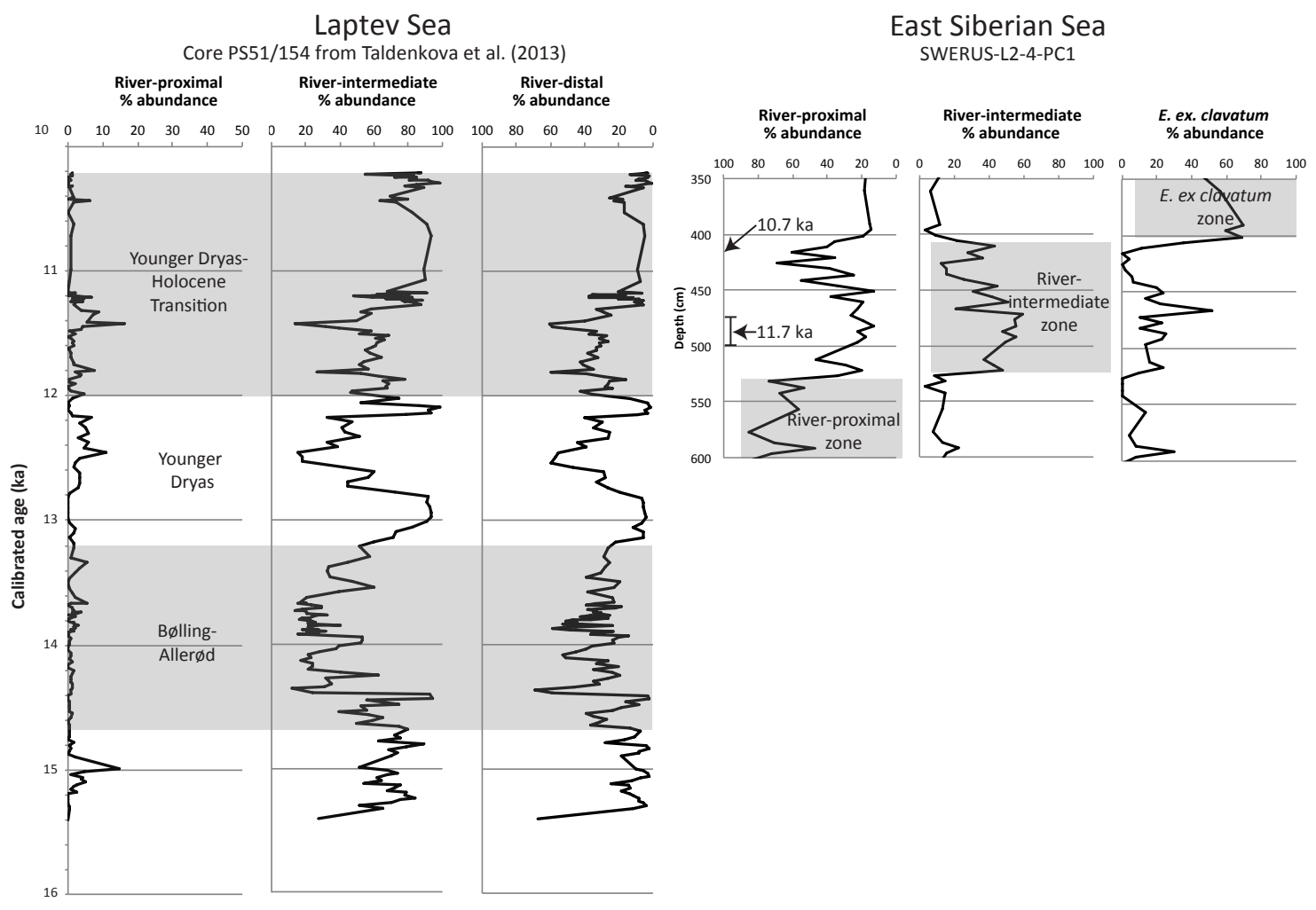

Figure 7. Comparison of benthic foraminifers in cores SWERUS-L2-4-PC1 and PS51/154 from the Laptev Sea (Taldenkova et al., 2013) using the assemblage scheme of river-proximal, river-intermediate, and river-distal taxa defined by Polyak et al. (2002). The shading marks key climatic intervals identified by Taldenkova et al. (2013) and informal foraminiferal zones in core 4-PC. River-proximal species dominate from 530 to $600 \mathrm{~cm}$ of core depth in 4-PC1 on the East Siberian Sea margin. In contrast, river-proximal species are generally rare (usually $<10 \%)$ in PS51/154 due to the greater water depth $(270 \mathrm{~m})$ and distance from shore for the core site compared to SWERUS-4-PC1 (120 m). Overlying the river-proximal zone in 4-PC1 is an interval with greatly increased proportions (40-50\%) of river-intermediate species, suggesting deeper water due to regional sea level transgression. This zone is dated at 12 to $10.7 \mathrm{ka}$, mainly the post-Younger Dryas and transition into the Holocene (Preboreal) period. Oscillations in foraminiferal assemblages in core PS51/154 coincide with those in SWERUS-4-PC1; however, those in PS51/154 signify water mass changes on the upper slope rather than salinity changes due to changes in the rate of sea level rise and proximity to freshwater river influx. Late Holocene foraminiferal assemblages at 4-PC1 (not shown) are dominated by E. excavatum clavata.

the evidence from the physical properties (higher sand content, high magnetic susceptibility and bulk density; Figs. 2, 3) for shallow marine environments at about 13.5 to $12 \mathrm{ka}$. The lithologic transition at $520-510 \mathrm{~cm}$ (Fig. 2) coincides with the faunal shift in foraminiferal assemblages (Fig. 5). The core 4-PC1 river-intermediate assemblage centered at about 12 ka suggests an early to mid-Younger Dryas transgression of this region, although the rate of transgression cannot be quantified from the faunal shifts alone, and additional study of the age of the lowermost sediments in 4-PC1 is needed. Above this assemblage, there is an unconformity or condensed interval, presumably after the final phase of postglacial SLR had breached the Bering Strait and fully submerged the continental shelf (Jakobsson et al., 2017). Sediment accumulation rates increased again during the late Holocene.
There are additional benthic foraminiferal records from the Eurasian shelf and slope indicating oceanographic changes during the Younger Dryas and early Holocene intervals. Figure 7 compares the benthic foraminiferal data from core 4-PC1 with the foraminiferal data from core PS51/154 (270 MWD) from the Laptev Sea (Taldenkova et al., 2013). We used the assemblage scheme of river-proximal, riverintermediate, and river-distal taxa defined by Polyak et al. (2002). Gray shading marks the key climatic intervals identified by Taldenkova et al. (2013) and suggested by the informal foraminiferal zones in core 4-PC1. River-proximal species, which dominate from 530 to $600 \mathrm{~cm}$ of core depth in core 4-PC1 on the Chukchi Sea margin, are, in contrast, generally rare (usually $<10 \%$ ) in core PS51/154. This change in abundance is expected due to the greater water depth $(270 \mathrm{~m})$ and distance from shore for PS51/154 compared to core 4PC1 $(120 \mathrm{~m})$. Overlying the river-proximal zone in core 4- 
PC1 is an interval with greatly increased proportions $(40$ $50 \%)$ of river-intermediate species, suggesting deeper water due to regional sea level transgression. This assemblage, dated at 12 to $10.7 \mathrm{ka}$, was deposited during the late Younger Dryas and transition into the Holocene (Preboreal) period.

Coeval oscillations in foraminiferal assemblages in core PS51/154 coincide with those in 4-PC1; however, those in core PS51/154 signify water mass changes on the upper slope rather than changes in salinity due to a greater rate of SLR and greater distance to freshwater river influx. Late Holocene foraminiferal assemblages in core 4-PC1 (not shown) are typical of many Arctic shelf environments and are dominated by E. excavatum clavata.

\subsection{Regional sea level datums: deglacial sea level in the western Arctic}

Relative sea level datums were calculated for intervals in cores 4-PC1 and 20-GC dated at approximately 13.5-10.7 ka as follows. The depth of the core interval containing the ${ }^{14} \mathrm{C}$ dated, nearshore ostracode and river-proximal foraminiferal assemblages (600-400 $\mathrm{cm}$ of core depth for core 4-PC1) was added to the modern water depth of $120 \mathrm{~m}$ at the core site, and then the paleo-water depth $(17 \mathrm{~m}$ on the basis of preferred modern depths for C. macchesneyi, P. pseudopunctillata, Rabilimis) was subtracted. This gives a paleoshoreline datum near $13.5-12.5 \mathrm{ka}$ at about $108 \mathrm{~m}$ b.s.l. at the Herald Canyon site. A similar calculation for core 20-GC, the river-proximal assemblage (mean core depth $73 \mathrm{~cm}$ ) plus water depth at the core site $(115 \mathrm{~m})$ minus paleodepth $(\sim 14 \mathrm{~m}$ based on $H$. sorbyana), yields a paleoshoreline of $102 \mathrm{~m}$. These estimates of 108 and $102 \mathrm{~m}$ should be viewed as approximate, although they are based on the large amount of ecological literature given above. There is a possibility that the datum for core 20-GC is several centuries younger if one omits the two radiocarbon ages from possibly reworked shells. The postYounger Dryas (post-11.7 ka) rate of SLR cannot be quantified, but very likely it was faster than the rate during the Younger Dryas on the basis of coral reef records.

It is useful to compare relative sea level for the late deglacial period with the estimated sea level for this region from the ICE-6G (VM5a) geophysical model of Peltier et al. (2015, Argus et al., 2014). ICE-6G (VM5a) is the latest version of geophysical models of Earth surface boundary conditions from the LGM and most recent deglaciation in response to the change in mass distribution as ice sheets melted. The newest version has additional refinements applying global positioning system (GPS) measurements of vertical crustal movements, which are verified by recent Gravity Recovery and Climate Experiment (GRACE) satellite data. Expected paleo-water depth histories near our core sites were determined in two steps: (1) the modern $(t=0 \mathrm{ka})$ depth below sea level was calculated as the sum of the shipboard core collection water depth and sample sediment depth for each SL datum. No additional correction for sediment compaction
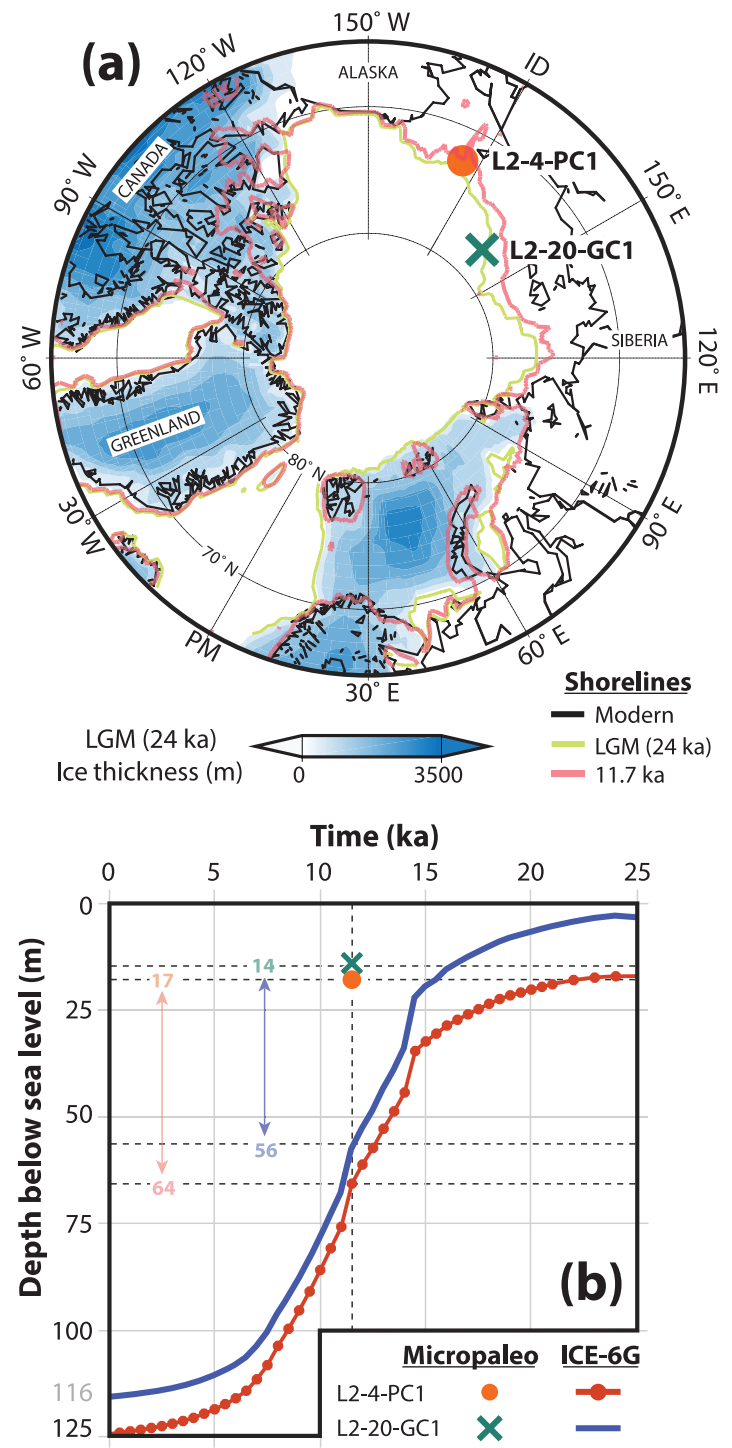

Figure 8. (a) Map showing modern, Younger Dryas, and LGM shorelines based on the ICE-6G model of Peltier et al. (2015). LGM ( $24 \mathrm{ka}$ ) ice sheet extent and thickness are designated by blue shading. A green " $\mathrm{X}$ " and orange dot mark the locations of core sites 20-GC1 and 4-PC1, respectively. (b) The orange dot and green " $\mathrm{X}$ " show paleo-Younger Dryas (about $11.7 \mathrm{ka}$ ) water depth estimates based on microfaunal assemblages. Expected paleo-water depth histories for the 20-GC1 and 4-PC1 sites are given by the blue solid and red dotted line, respectively.

was made. (2) Then, we subtracted the modeled ICE-6G topography difference from the present (Topo_Diff) at time $t$ from the value calculated in step 1 . This approach was used in place of the absolute model topography due to its coarse discretization in the model $\left(1^{\circ}\right.$ latitude $\times 1^{\circ}$ longitude).

For the East Siberian Sea, the ICE-6G model predicts a paleo-water depth of $64 \mathrm{~m}$ b.s.l. at around $\sim 11.7 \mathrm{ka}$. The paleodepth estimates reported above on the basis of microfau- 
nal assemblages diverge from modeled, deglacial sea level estimates (Fig. 8). For cores 4-PC1 and 20-GC1, the modeled depths for a minimum age of $\sim 11.7 \mathrm{ka}$ are respectively 47 and $42 \mathrm{~m}$ deeper than the estimates based on microfaunal depth zonation and the chronological constraints described above. While a fraction of this offset might be explained by hydro-isostasy (e.g., Klemann et al., 2015), this discrepancy might also be reconciled by (1) the presence of East Siberian Sea ice cover, perhaps on the continental shelf, (2) a forebulge along the ice periphery, and (3) a subsequent collapse following deglaciation. At present little evidence for LGM ice has been found in the East Siberian Sea or the Chukchi Sea, and previous suggestions for circum-Arctic glaciation (Grosswald and Hughes, 2002) conflict with apparent "icefree" LGM conditions on Wrangel Island $\left(71^{\circ} \mathrm{N}, 179^{\circ} \mathrm{W}\right)$ and elsewhere in Eastern Siberia (e.g., Gualtieri et al., 2003 and references therein). However, given that surveys only recently identified widespread scouring by a large $\sim 1 \mathrm{~km}$ thick Arctic ice shelf during recent glacial periods (Polyak et al., 2001; Niessen et al., 2013; Jakobsson et al., 2016), the results presented here give cause for continued exploration in search of LGM glacial landforms submerged along Arctic continental margins.

Two major conclusions can be drawn from the new findings from Leg 2 of the SWERUS-C3 expedition: (1) the late deglacial regional sea level along the East Siberian Sea margin at the end of the Younger Dryas was up to $42-47 \mathrm{~m}$ lower than levels expected from geophysical models of glacioisostatic response to the last deglaciation, and (2) there appears to be evidence from both the Herald Canyon and East Siberian Sea margin sites of a relatively rapid rise in sea level following the Younger Dryas. Although it is difficult to estimate the rate of SLR, the age seems to correspond to meltwater pulse $1 \mathrm{~B}$ and would thus be considered evidence for global sea level rise. Arctic Ocean deglacial sea level history remains incomplete, however, and it will be necessary in future studies to extend the deglacial sea level record back to the early stages of deglaciation prior to the Younger Dryas.

Data availability. The data are mostly contained in the paper itself in the tables and Supplement.

\section{The Supplement related to this article is available online at https://doi.org/10.5194/cp-13-1097-2017-supplement.}

Competing interests. The authors declare that they have no conflict of interest.

Special issue statement. This article is part of the special issue "Climate-carbon-cryosphere interactions in the East Siberian Arctic
Ocean: past, present and future (TC/BG/CP/OS inter-journal SI)". It does not belong to a conference.

Acknowledgements. We are grateful to the captain and crew of the Oden for assistance in carrying out the SWERUS-C3 Leg 2 expedition. Special thanks go to Jan Backman for shipboard direction, Carina Johansson, Natalia Macho Barrientos, and Pedro Pietro for shipboard laboratory work, and to Alexandr Gukov for mollusc identifications. Marci Robinson and Christopher Swezey provided useful reviews of the paper. Funding was provided by the US Geological Survey Climate and Land Use R\&D Program and the Knut and Alice Wallenberg Foundation (KAW) for the SWERUS-C3 expedition. Additional support came from the Swedish Research Council (Jakobsson, 2012-1680; O'Regan, 2012-3091) and the Danish Council for Independent Research (Pearce, grant no. DFF-4002-00098_FNU). Two reviewers provided valuable insights that greatly improved the revised paper. Igor Semiletov acknowledges support from the Russian government (grant no. 14.Z50.31.0012/03.19.14).

Edited by: Carlo Barbante

Reviewed by: Ekaterina Taldenkova and one anonymous referee

\section{References}

Argus, D. F., Peltier, W. R., Drummond, R., and Moore, A. W.: The Antarctic component of postglacial rebound Model ICE-6G_C (VM5a) based upon GPS positioning, exposure age dating of ice thicknesses and sea level histories, Geophys. J. Int., 198, 537563, https://doi.org/10.1093/gji/ggu140, 2014.

Arndt, J. E., Niessen, F., Jokat, W., and Dorschel, B.: Deep water paleo-iceberg scouring on top of Hovgaard RidgeArctic Ocean, Geophys. Res. Lett., 41, 2014GL060267, https://doi.org/10.1002/2014GL060267, 2014.

Bauch, H. A., Mueller-Lupp, T., Taldenkova, E., Spielhagen, R. F., Kassens, H., Grootes, P. M., Thiede, J., Heinemeier, J., and Petryashov, V. V.: Chronology of the Holocene transgression at the North Siberian margin, Global Planet. Change, 31, 125-139, https://doi.org/10.1016/S0921-8181(01)00116-3, 2001.

Bronk Ramsey, C.: Deposition models for chronological records, Quaternary Sci. Rev., 27, 42-60, https://doi.org/10.1016/j.quascirev.2007.01.019, 2008.

Bronk Ramsey, C.: Bayesian Analysis of Radiocarbon Dates, Radiocarbon, 51, 337-360, https://doi.org/10.2458/azu_js_rc.v51i1.3494, 2009.

Carbonara, K., Mezgec, K. Varagona, G., Musco, M. E. Lucchi, R. G., Villa, G., Morigi, C., Melis, R., and Caffau, M.: Palaeoclimatic changes in Kveithola, Svalbard, during the Late Pleistocene deglaciation and Holocene: Evidences from microfossil and sedimentary records, Palaeogeogr. Palaeocl., 463, 136-149, https://doi.org/10.1016/j.palaeo.2016.10.003, 2016.

Cronin, T. M., Vogt, P. R., Willard, D. A., Thunell, R., Halka, J., Berke, M., and Pohlman, J.: Rapid sea level rise and ice sheet response to 8,200-year climate event, Geophys. Res. Lett., 34, 1-6, L20603, https://doi.org/10.1029/2007GL031318, 2007.

Cronin, T. M.: Chapter 16. Ostracodes and sea level, in: Handbook of Sea-Level Research, First Edition, edited by: Shennan, 
I., Long, A. J., and Horton, B. P., John Wiley \& Sons, Ltd., 249257, 2015.

Dove, D., Polyak, L., and Coakley, B.: Widespread, multi-source glacial erosion on the Chukchi margin, Arctic Ocean, Quaternary Sci. Rev., 92, 112-122, 2014.

Edwards, R. and Wright, A.: Foraminifera. Chapter 13, in: Handbook of Sea-Level Research, First Edition, edited by: Shennan, I., Long, A. J., and Horton, B. P., John Wiley \& Sons, Ltd., 191217, 2015.

Engels, J. L., Edwards, M. H., Polyak, L., and Johnson, P. D.: Seafloor evidence for ice shelf flow across the Alaska-Beaufort margin of the Arctic Ocean, Earth Surf. Proc. Land., 32, 1-17, 2008.

Gemery, L., Cronin, T. M. Briggs Jr., W. M., Brouwers, E. M., Schornikov, E. I., Stepanova, A., Wood, A. M., and Yasuhara, M.: An Arctic and Subarctic Ostracode Database: Biogeographic and Paleoceanographic Applications, Hydrobiologica, 786, 5995, https://doi.org/10.1007/s10750-015-2587-4, 2015.

Grosswald, M. G. and Hughes, T. J.: The Russian component of an Arctic Ice Sheet during the Last Glacial Maximum, Quaternary Sci. Rev., 21, 121-146, 2002.

Gualtieri, L., Vartanyan, S., Brigham-Grette, J., and Anderson, P.: Pleistocene raised marine deposits on Wrangel Island, northeast Siberia and Implications for the Presence of an East Siberian Ice Sheet, Quaternary Res., 59, 399-410, 2003.

Hald, M.: Late Glacial and Holocene paleoceanography and sedimentary environments in the Saint Anna Trough, Eurasian Arctic Ocean Margin, Palaeogeogr. Palaeocl., 146, 229-249, 1999.

Hald, M., Ebbesen, H., Forwick, M., Godtliebsen, F., Khomenko, L., Korsun, S., Olsen, L. R., and Vorren, T. O.: Holocene paleoceanography and glacial history of the West Spitsbergen area, Euro-Arctic margin, Quaternary Sci. Rev., 23, 2075-2088, 2004.

Ishman, S. E., Polyak, L., and Poore, R. Z.: An expanded record of Pleistocene deep Arctic change: Canada Basin, western Arctic Ocean, Geology, 24, 139-142, 1996.

Jakobsson, M., Nilsson, J., O’Regan, M., Backman, J., Löwemark, L., Dowdeswell, J. A., Mayer, L., Polyak, L., Colleoni, F., Anderson, L. G., Björk, G., Darby, D., Eriksson, B., Hanslik, D., Hell, B., Marcussen, C., Sellén, E., and Wallin, Å.: An Arctic Ocean ice shelf during MIS 6 constrained by new geophysical and geological data, Quaternary Sci. Rev., 29, 3505-3517, 2010.

Jakobsson, M., Andreassen, K., Bjarnadóttir, L. R., Dove, D., Dowdeswell, J. A., England, J. H., Funder, S., Hogan, K., Ingólfsson, Ó., Jennings, A., Krog Larsen, N., Kirchner, N., Landvik, J. Y., Mayer, L., Mikkelsen, N., Möller, P., Niessen, F., Nilsson, J., O'Regan, M., Polyak, L., Nørgaard-Pedersen, N., and Stein, R.: Arctic Ocean glacial history: Quaternary Sci. Rev., 92, 40-67, 2014.

Jakobsson, M., Nilsson, J., Anderson, L., Backman, J., Björk, G., Cronin, T. M., Kirchner, N., Koshurnikov, A., Mayer, L., Noormets, R., O'Regan, M., Stranne, C, Ananiev, R., Barrientos Macho, N., Cherniykh, D., Coxall, H., Eriksson, B., Flodén, T., Gemery, L., Gustafsson, O., Jerram, J., Johansson, C., Khortov, A., Mohammad, R. and Semiletov, I.: Evidence for an ice shelf covering the central Arctic Ocean during the penultimate glaciation, Nat. Commun., 7, 10365, https://doi.org/10.1038/ncomms10365, 2016.

Jakobsson, M., Pearce, C., Cronin, T. M., Backman, J., Anderson, L. G., Barrientos, N., Björk, G., Coxall, H., de Boer, A.,
Mayer, L. A., Mörth, C.-M., Nilsson, J., Rattray, J. E., Stranne, C., Semiletov, I., and O'Regan, M.: Post-glacial flooding of the Bering Land Bridge dated to $11 \mathrm{cal} \mathrm{kaBP}$ based on new geophysical and sediment records, Clim. Past, 13, 991-1005, https://doi.org/10.5194/cp-13-991-2017, 2017.

Jennings, A., Walton, M. E., Cofaigh, C. Ó., Kilfeather, A., Andrews, J. T., Ortiz, J. D., de Vernal, A., and Dowdeswell, J. A.: Paleoenvironments during Younger Dryas-Early Holocene retreat of the Greenland Ice Sheet from outer Disko Trough, central west Greenland, J. Quaternary Sci., 29, 27-40, https://doi.org/10.1002/jqs.2652TS5, 2014.

Klemann, V., Heim, B., Bauch, H. A., Wetterich, S., and Opel, T.: Sea-level evolution of the Laptev Sea and the East Siberian Sea since the Last Glacial Maximum - impact of glacial isostatic adjustment, Arktos, The Journal of Arctic Geosciences, 1, 1-8, https://doi.org/10.1007/s41063-015-0004-x, 2015.

Knudsen, K. L., Jiang, H., Jansen, E., Eiríksson, J., Heinemeier, J., and Seidenkrantz, M.-S.: Environmental changes off North Iceland during the deglaciation and the Holocene: foraminifera, diatoms and stable isotopes, Mar. Micropaleontol., 50, 273-305, 2004.

Korsun, S. and Hald, M.: Modern benthic foraminifera off Novaya Zemlya tidewater glaciers, Russian Arctic, Arctic Alpine Res., 30, 61-77, 1998.

Lambeck, K., Antonioli, F., Anzidei, M., Ferranti, L., Leoni, G., Scicchitano, G., and Silenzi, S.: Sea level change along the Italian coast during the Holocene and projections for the future, Quaternary Int., 232, 250-257, 2011.

Lambeck, K., Rouby H., Purcell, A., Sun, Y., and Sambridge M.: Sea level and global ice volumes from the Last Glacial Maximum to the Holocene, P. Natl. Acad. Sci. USA, 111, 15296-15303, 2014.

Matthiessen, J., Knies, J., Nowaczyk, N. R., and Stein, R.: Late Quaternary dinoflagellate cyst stratigraphy at the Eurasian continental margin, Arctic Ocean: indications for Atlantic water inflow in the past 150,000 years, Global Planet. Change, 31, 65-86, 2001.

McDougall, K.: Late Cenozoic Benthic Foraminifers of the HLA Borehole Series, Beaufort Sea Shelf, Alaska, U.S. Geological Survey Bulletin 2055, 1994.

Niessen, F., Hong, J. K., Hegewald, A., Matthiessen, J., Stein, R., Kim, H., Kim, S., Jensen, L., Jokat, W., Nam, S.-I., and Kang, S.-H.: Repeated Pleistocene glaciation of the East Siberian continental margin, Nat. Geosci., 6, 842-846, 2013.

Nørgaard-Pederson, N., Spielhagen, R. F., Erlenkeusser, H., Grootes, P. M., Heinemeier, J., and Knies, J.: Arctic Ocean during the Last Glacial Maximum: Atlantic and polar domains of surface water mass distribution and ice cover, Paleoceanography, 18, 1063, https://doi.org/10.1029/2002PA000781, 2003.

Osterman, L. E., Poore, R. Z., and Foley, K. M.: Distribution of Benthic Foraminifers $(>125 \mu \mathrm{m})$ in the Surface Sediments of the Arctic Ocean, U.S. Geological Survey Bulletin, 2164, 1999.

Osterman, L. E., Buzas, M. A., and Hayek, L.-A. C.: SHE Analysis for Biozonation of Benthic Foraminiferal Assemblages from Western Arctic Ocean, Palaios, 17, 297-303, 2002.

Pearce, C., Varhelyi, A., Wastegård, S., Muschitiello, F., Barrientos, N., O’Regan, M., Cronin, T. M., Gemery, L., Semiletov, I., Backman, J., and Jakobsson, M.: The $3.6 \mathrm{ka}$ Aniakchak tephra in the Arctic Ocean: a constraint on the Holocene radiocar- 
bon reservoir age in the Chukchi Sea, Clim. Past, 13, 303-316, https://doi.org/10.5194/cp-13-303-2017, 2017.

Peltier, W. R.: Global Glacial Isostasy and the Surface of the IceAge Earth: The ICE-5G (VM2) Model and GRACE, Invited Paper, Annu. Rev. Earth Pl. Sc., 32, 111-149, 2005.

Peltier, W. R., Argus, D. F., and Drummond, R.: Space geodesy constrains ice age terminal deglaciation: The global ICE-6G_C (VM5a) model, J. Geophys. Res.-Sol. Ea., 120, 450-487, https://doi.org/10.1002/2014JB011176, 2015.

Poirier, R. K., Cronin, T. M., Briggs Jr., W. M., and Lockwood, R.: Central Arctic paleoceanography for the last $50 \mathrm{kyr}$ based on ostracode faunal assemblages, Mar. Micropaleontol., 88-89, 6576, 2012.

Polyak, L., Edwards, M. H., Coakley, B. J., and Jakobsson, M.: Ice shelves in the Pleistocene Arctic Ocean inferred from glaciogenic deep-sea bedforms, Nature, 410, 453-459, 2001.

Polyak, L., Korsun, S., Febo, L. A., Stanovoy, V., Khusid, T., Hald, M., and Lubinski, D. J.: Benthic foraminiferal assemblages from the southern Kara Sea, a river-influenced arctic marine environment, J. Foramin. Res., 32, 252-273, 2002.

Polyak, L., Curry, W. B., Darby, D. A., Bischof, J., and Cronin, T. M.: Contrasting glacial/interglacial regimes in the western Arctic Ocean as exemplified by a sedimentary record from the Mendeleev Ridge, Palaeogeogr. Palaeocl., 203, 73-93, 2004.

Polyak, L., Darby, D., Bischof, J., and Jakobsson, M.: Stratigraphic constraints on late Pleistocene glacial erosion and deglaciation of the Chukchi margin, Arctic Ocean, Quaternary Res., 67, 234245, 2007.

Rasmussen, T. L. and Thomsen, E.: Paleoceanographic development in Storfjorden, Svalbard, during the deglaciation and Holocene: evidence from benthic foraminiferal records, Boreas, 44, 24-44, https://doi.org/10.1111/bor.12098, 2014.

Reimer, P. J. and Reimer, R. W.: A marine reservoir correction database and on-line interface, Radiocarbon, 43, 2a, 461-463, 2001.

Reimer, P. J., Bard, E., Bayliss, A., Beck, J. W., Blackwell, P. G., Bronk Ramsey, C., Grootes, P. M., Guilderson, T. P., Haflidason, H., Hajdas, I., Hatté, C., Heaton, T. J., Hoffmann, D. L., Hogg, A. G., Hughen, K. A., Kaiser, K. F., Kromer, B., Manning, S. W., Niu, M., Reimer, R. W., Richards, D. A., Scott, E. M., Southon, J. R., Staff, R. A., Turney, C. S. M., and van der Plicht, J.: IntCal13 and Marine13 Radiocarbon Age Calibration Curves 0-50,000 Years cal BP, Radiocarbon, 55, 1869-1887, https://doi.org/10.2458/azu_js_rc.55.16947, 2013.

Scott, D. B., Schell, T., Rochon, A., and Blasco, S.: Benthic foraminifera in the surface sediments of the Beaufort Shelf and slope, Beaufort Sea, Canada: Applications and implications for past sea-ice conditions, J. Mar. Syst., 74, 840-863, 2008.

Scott, D. B., Schell, T., St-Onge, G., Rochon, A., and Blasco, S.: Foraminiferal assemblage changes over the last 15,000 years on the Mackenzie/ Beaufort sea slope and Amundsen Gulf, Canada: implications for past sea-ice conditions, Paleoceanography, 24, PA2219, https://doi.org/10.1029/2007PA001575, 2009.
Steffen, H. and Wu, P.: Glacial isostatic adjustment in Fennoscandia - A review of data and modeling, J. Geodyn., 52, 169-204, 2011.

Steffensen, J. P., Andersen, K. K., Bigler, M., Clausen, H. B., DahlJensen, D., Fischer, H. Goto-Azuma, K., Hansson, M., Johnsen, S. J., Jouzel, J., Masson-Delmotte, V., Popp, T., Rasmussen, S. O., Röthlisberger, R., Ruth, U., Stauffer, B., Siggaard-Andersen, M.-L., Sveinbjörnsdóttir, A. E., Svensson, A., and White, J. W. C.: High-Resolution Greenland Ice Core Data Show Abrupt Climate Change Happens in Few Years, Science, 321, 680-684, 2008.

Stepanova, A.: Late Pleistocene-Holocene and Recent Ostracoda of the Laptev Sea and their importance for paleoenvironmental reconstructions, Paleontol. J., 40, S91-S204, 2006.

Svendsen, J. I., Alexanderson, H., Astakhov, V. I., Demidov, I., Dowdeswell, J. A., Henriksen, M., Hjort, C., Houmark-Nielsen, M., Hubberten, H. W., Ingólfson, O., Jakobsson, M., Kjær, K., Larsen, E., Lokrantz, H., Lunkka, J. P., Lyså, A., Mangerud, J., Maslenikova, O., Matioushkov, A., Murray, A., Möller, P., Niessen, F., Saarnisto, M., Siegert, C., Stein, R., Siegert, M. J., and Spielhagen, R.: Late Quaternary ice sheet history of northern Eurasia, Quaternary Sci. Rev., 23, 1229-1271, 2004.

Taldenkova, E., Bauch, H. A., Stepanova, A., Ovsepyan, Y., Pogodina, I., Klyuvitkina, T., and Nikolaev, S.: Benthic and planktic community changes at the North Siberian margin in response to Atlantic water mass variability since last deglacial times, Mar. Micropaleontol., 99, 29-44, https://doi.org/10.1016/j.marmicro.2013.03.010, 2013.

Wollenburg, J. E. and Kuhnt, W.: The response of benthic foraminifers to carbon flux and primary production in the Arctic Ocean, Mar. Micropaleontol., 40, 189-231, 2000.

Wollenburg, J. E. and Mackensen, A.: Living benthic foraminifers from the central Arctic Ocean: faunal composition, standing stock and diversity, Mar. Micropaleontol., 34, 153-185, 1998.

Wollenburg, J. E., Knies, J., and Mackensen, A.: High-resolution paleoproductivity fluctuations during the past $24 \mathrm{kyr}$ as indicated by benthic foraminifera in the marginal Arctic Ocean, Palaeogeogr. Palaeocl., 204, 209-238, 2004.

Wollenburg, J. E., Mackensen, A., and Kuhnt, W.: Benthic foraminiferal biodiversity response to a changing Arctic palaeoclimate in the last 24,000 years, Palaeogeogr. Palaeocl., 255, 195-222, https://doi.org/10.1016/j.palaeo.2007.05.007, 2007.

Yasuhara, M., Stepanova, A., Okahashi, H., Cronin, T. M., and Brouwers, E. M.: Taxonomic revision of deep-sea Ostracoda from the Arctic Ocean, Micropaleontology, 60, 399-444, 2014. 